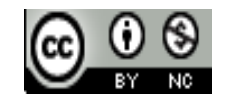

Journal of Education, Teaching, and Learning is licensed under

A Creative Commons Attribution-Non Commercial 4.0 International License.

\title{
Evaluation of Learning Outcome Assessment System in Health and Sports Physical Education Subject in Junior High School
}

\author{
Ismail $^{1)}$, Indri Astuti ${ }^{2)}$, Aloysius Mering ${ }^{3)}$ \\ 1) Universitas Tanjungpura, Pontianak, Indonesia \\ E-mail: ismailsaputra04@gmail.com \\ 2) Universitas Tanjungpura, Pontianak, Indonesia \\ E-mail: indribk91@yahoo.com \\ 3) Universitas Tanjungpura, Pontianak, Indonesia \\ E-mail: mering7157@yahoo.co.id
}

\begin{abstract}
Research aims to find out: (1) context of learning outcome assessment system, (2) input evaluation of the results assessment system, (3) component of the assessment system implementation process, (4) product learning outcomes assessment system. This study includes evaluation research with the CIPP M\model (context, input, process, product) with a qualitative and quantitative approach and using qualitative descriptive analysis methods. Data collection techniques used are (1) questionnaires, (2) observation, (3) interviews and (4) documentation. Data analysis techniques for quantitative data are (1) editing, (2) coding, and (3) tabulating. For qualitative data are: (1) data reduction, (2) presentation of data, and (3) draw conclusions. Results of the study: (1) the target of assessing learning outcome in PJOK subjects in Ketapang Junior High School is still lacking, such as in the assessment instrument between friends, journal, projects. (2) preparation of the semester program is not prepared a special time for daily tests. In the preparation of the RPP which small teachers were still not included in the problem text, key answers, and assessment guidelines. (3) the assessment process is not in accordance with the time specified, the teacher has not optimally discussed midterm exam questions. (4) reports on the assessment of student learning outcomes include affective, cognitive and psychomotor aspects, as well as the report, contains descriptive notes that are useful for parent and a follow up in efforts to improve the learning process in general. The assessment system of learning outcomes in PJOK subjects in Ketapang Junior High School is in accordance with the 2013 curriculum assessment guidelines. In the implementation of the assessment, it is expected that the participation of principals, supervisors and relevant agencies, in order to provide technical guidance to teachers in the assessment process so that the assessment process is carried out maximum in accordance with the 2013 curriculum.
\end{abstract}

Keywords: Evaluation; Learning Outcome; Assessment System

\section{INTRODUCTION}

Assessment of learning outcomes is one of the most important activities in the world of education. With a good assessment of learning outcomes, it can be known the level of student learning progress, its weaknesses, and strengths. Assessment of good learning outcomes will be a feedback for the teacher to evaluate the level of success of the teaching and learning process. Through evaluation, educators can better guide their students to achieve maximum learning outcomes, both from the cognitive, affective, and psychomotor aspects. Evaluation can play a role in anticipating and preventing the failure of the learning process. With the evaluation, it is expected to make learning better and lack of learning can be improved. So that learning objectives can be achieved. Evaluation of this assessment system is carried out for all subjects at all levels of education including Physical and Health Physical Education subjects.

Evaluation is part of a series of learning in addition to the planning and implementation of learning. One important aspect of learning evaluation is assessment. Assessment is part of learning activities carried out to determine the achievement of students' competencies which include knowledge, attitudes, and skills. Assessment is carried out during the learning process and at the end of learning. The focus of educational assessment is the learning success of students in achieving the specified competency standards. A good assessment system will affect learning outcomes. To find out the implementation of the system of assessing Health 
and Sports Physical Education learning outcomes in accordance with the standards of assessment guidelines by the education unit, an evaluation is needed.

This is in line with the results of Sadikun's research (2015) which shows that in general the implementation of the assessment system in schools has been carried out in accordance with the guidelines, but there are many deficiencies in the implementation. As for the drawback that the semester program does not contain the time to carry out repetition of repairs and enrichment, the syllabus does not include assessment techniques for aspects of attitude, cognitive and psychomotor aspects not relevant to basic competencies, assessment in RPP does not cover all learning objectives and still found assessment techniques that are not relevant to Learning objectives, assessment of affective aspects through journals are not carried out, affective value processing is not in accordance with the assessment guidelines of the Ministry of Education and Culture, written tests in the form of free descriptions are very few, the process of implementing portfolio assessments is not in accordance with the provisions of portfolio assessment, spiritual attitude competence in the book report cards are not in accordance with the basic competencies of spiritual attitudes in the curriculum, and the descriptive values of report cards do not explain the achievement of the most prominent or good competencies and the competencies whose achievements are still lacking.

Similarly, the results of Ani Widayanti (2014) study that the preparation of portfolios which includes planning, planning, assigning tasks, compiling content, dialogue and storing portfolios is not good, teachers carry out portfolio assessments in accordance with their simple understanding. In the study of Ismiyati (2011) that the implementation of assessments by lecturers according to students and lecturers themselves is in good category.

Based on the results of observations and direct observations carried out at the school of Ketapang 1 State Junior High School, Ketapang 2 State Junior High School, Ketapang 3 State Junior High School, Ketapang 4 State Junior High School, and Hulu Sungai 1 State Junior High School, information was obtained that there were still Health and Sports Physical Education teachers who had not carried out the implementation process assessment of learning outcomes in Health and Sports Physical Education subjects in accordance with the assessment standards set out in the 2013 Curriculum

.Based on the results of observations made, the overall assessment stages in Ketapang Junior High School have not been fully implemented by the teacher in assessing learning outcomes. This certainly shows that the stage of the assessment system has not been done optimally because it does not show a thorough assessment process in determining learning outcomes. Based on the description above, the researcher wants to do research on evaluating the assessment system of learning in Health and Sports Physical Education subjects in Ketapang Junior High School with the CIPP model (context, input, process, product)
In general, the aim of the researchers to achieve in this study is to describe and evaluate the implementation of the learning outcomes assessment system in Health and Sports Physical Education subjects in Ketapang Junior High School. Specifically, the purpose of this study is to describe: (1) Components of the context of evaluating the learning outcomes assessment system in Health and Sports Physical Education subjects in Ketapang Junior High School. (2) Components of input evaluation of learning outcomes in Health and Sports Physical Education subjects in Ketapang Junior High School. (3) Components of the implementation process of evaluating the learning outcomes assessment system in Health and Sports Physical Education subjects in Ketapang Junior High School. (4) The product component of the learning outcome assessment system in Health and Sports Physical Education subjects in Ketapang Junior High School.

\section{RESEARCH METHOD}

The research method used is qualitative descriptive method is a problem-solving method that is investigated by describing or describing the state of the object of research in the present state based on the facts that appear or as they are (Satori and Komariah (2013: 22). This method is used to see the implementation of the learning outcomes assessment system in Health and Sports Physical Education subjects in Ketapang Junior High School. The design of this research is evaluation research with CIPP Model (context, input, process, product). Subjects in this assessment were 9 Physical and Physical Education subject teachers, totaling 48 students, 48 students attending classes and 5 vice principals in the curriculum field. Data collection techniques in this study are questionnaire techniques, observation, interviews, and documentation. The research instrument was questionnaire guide, observation guide, interview guide and documentation guide. Data analysis techniques used in this study were quantitative and qualitative analysis.

\section{RESULT AND DISCUSSION}

A. Result

Respondents in this study consisted of 9 teachers, 48 students in grade VII and 5 students in the curriculum in Ketapang Junior High School. Data collection techniques in this study in the form of a teacher questionnaire with 56 items, student questionnaire with 52 items, observation with 70 statements, and interviews with 14 questions. The results of each respondent, in summary, can be seen in Figure 1, 2, 3 and 4 below: 


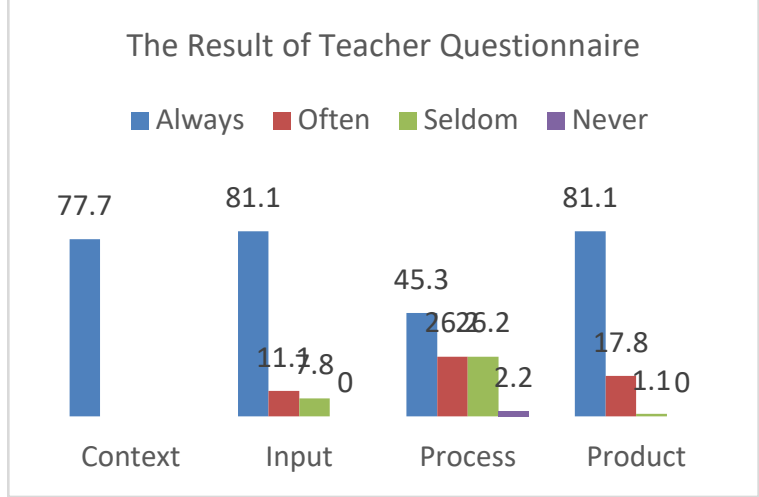

Fig. 1 Results of a teacher questionnaire evaluating the learning outcome assessment system in Health and Sports Physical Education subjects at Ketapang Junior High School.

In the graph 1. shows the percentage of the results of the teacher questionnaire in the implementation of the learning outcomes assessment system in Health and Sports Physical Education subjects in Ketapang Junior High School can be explained as follows:

1) In the aspect of context, $77.7 \%$ of teachers answered that they had implemented the learning outcome assessment objectives. This means that most teachers carry out the assessment of learning outcomes in Sports Physical and Health Education subjects.

2) In the aspect of input shows $81.1 \%$ of teachers answered always implementing the target of learning outcomes, $1.1 \%$ of teachers answered frequently, $7.8 \%$ of teachers answered sometimes and $0 \%$ answered never. This means that most teachers always carry out the assessment plan of learning outcomes in Sports Physical and Health Education subjects.

3) In the aspect of the process, $45.3 \%$ of the teachers answered that they always carried out the process of evaluating learning outcomes, $26.2 \%$ of teachers answered frequently, $26.2 \%$ of teachers answered sometimes and $2.2 \%$ of teachers answered never. This means that most teachers always carry out the process of assessing learning outcomes in Sports Physical and Health Education subjects.

4) In the product aspect, $45.3 \%$ of teachers answered that they always carried out the process of evaluating learning outcomes, $17.8 \%$ of teachers answered frequently, $1.1 \%$ of teachers answered sometimes and $0 \%$ answered never. This means that most teachers always carry out product learning outcomes assessment results in the Physical and Health Physical Education subjects.

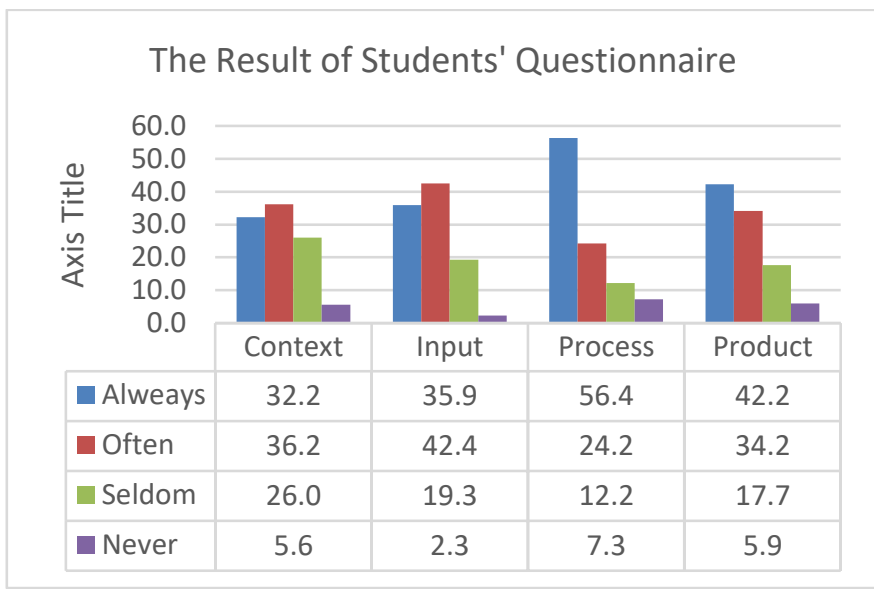

Fig. 2 Results of the students' questionnaire evaluating the learning outcomes assessment system in Health and Sports Physical Education subjects at Ketapang Junior High School.

In graph 2. shows the percentage of student questionnaire results in the implementation of the learning outcome assessment system in the Physical and Health Physical Education subjects at Ketapang Junior High School can be explained as follows:

(1) In the aspect of context, $32.2 \%$ of students answered that they always carried out the assessment of learning outcomes, $36.2 \%$ of students answered frequently, $26.0 \%$ of students answered sometimes, and $5.6 \%$ of students answered never. This means that most students answer that the teacher often carries out the assessment objectives of learning outcomes in Sports Physical and Health Education subjects.

(2) In the aspect of input shows $35.9 \%$ of students answered always carrying out the assessment plan of learning outcomes, $42.4 \%$ of students answered frequently, $19.2 \%$ of students answered sometimes and $2.3 \%$ of students answered never. This means that most teachers often carry out assessment planning for learning outcomes in Sports Physical and Health Education subjects.

(3) In the aspect of the process shows $56.4 \%$ of students answered always carrying out the assessment process of learning outcomes, $24.2 \%$ of students answered frequently, $12.2 \%$ of students answered sometimes and $7.3 \%$ of students answered never. This means that most teachers always carry out the process of assessing learning outcomes in Sports Physical and Health Education subjects.

(4) On the product aspect, $42.2 \%$ of students answered that they always carried out the assessment process of learning outcomes, $12.2 \%$ of students answered often, $1.1 \%$ of students answered sometimes and $7.3 \%$ of students answered never. This means that most teachers always carry out product learning outcomes assessment results in the Physical and Health Physical Education subjects. 


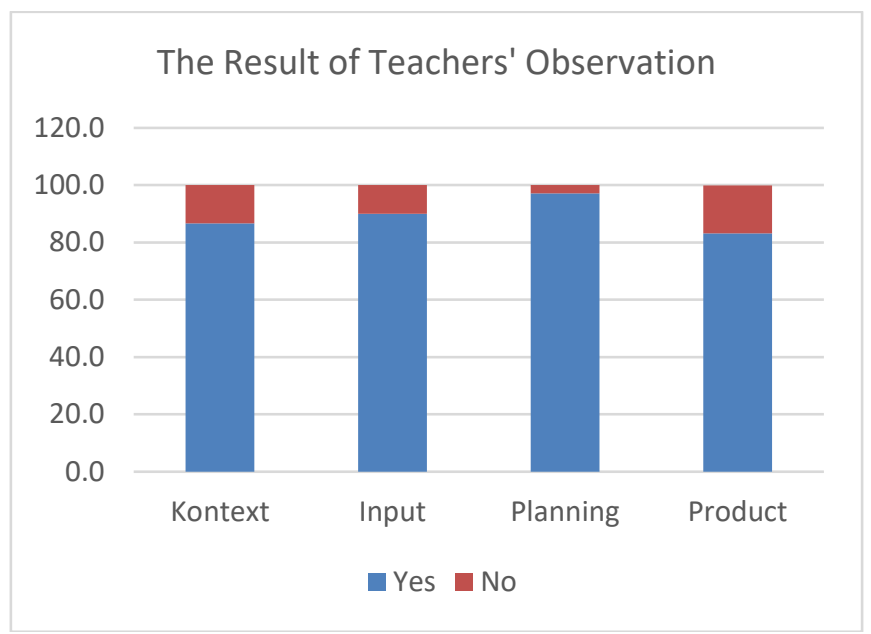

Fig. 3 The results of the teachers' observation in evaluating the learning outcomes assessment system in Health and Sports Physical Education subjects at Ketapang Junior High School.

In graph 3. shows the percentage of teacher observations in the implementation of the learning outcomes assessment system in Health and Sports Physical Education subjects in Ketapang Junior High School can be explained as follows:

1) In the context aspect, $86.7 \%$ stated "yes", the teacher implemented the target of learning outcomes, $13.3 \%$ stated "no", the teacher did not implement the learning outcome assessment goal. This means that most of the teachers stated that they had carried out the assessment objectives of learning outcomes in Sports Physical and Health Education subjects

2) In the input, aspect shows $90 \%$ stated "yes", the teacher carried out the assessment plan of learning outcomes, $10 \%$ said "no", the teacher did not carry out the assessment plan of learning outcomes. This means that most teachers state that they have implemented an assessment plan for learning outcomes in Sports Physical and Health Education subjects.

3) In the aspect of the process, $90 \%$ stated "yes", the teacher carried out the assessment plan of learning outcomes, $10 \%$ stated "no", the teacher did not carry out the assessment process of learning outcomes. This means that most of the teachers stated that they had carried out the assessment process of learning outcomes in Sports Physical and Health Education subjects

4) In the aspect of the product, $97.1 \%$ of the students answered that they always said "yes", the teacher carried out the assessment of learning outcomes, 2.9\% said "no", the teacher did not carry out the assessment plan of learning outcomes. This means that some teachers state that they have carried out assessment products for learning outcomes in Sports Physical and Health Education subjects.

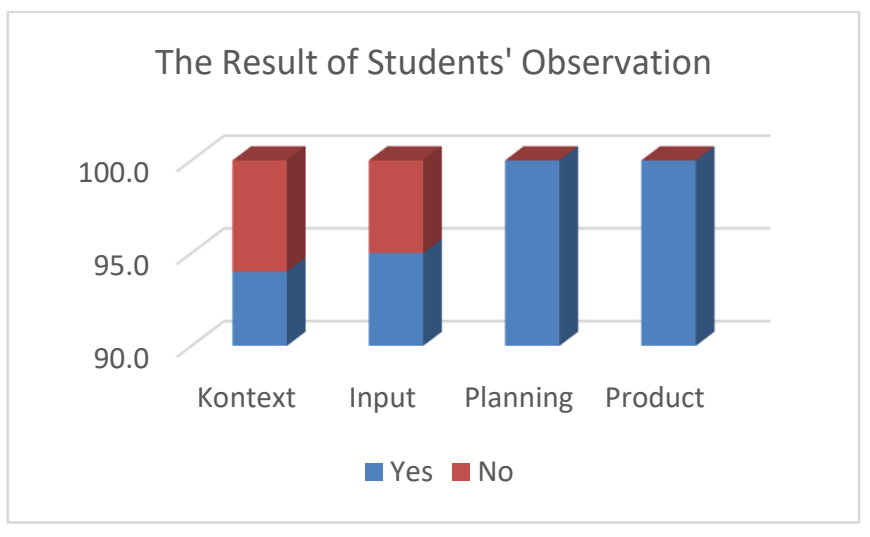

Fig.4 Interview results of evaluation of learning outcomes assessment system in Health and Sports Physical Education subjects at Ketapang Junior High School.

On graph 4. shows the percentage of interview results in the field of curriculum in the curriculum field in the implementation of the learning outcome assessment system in the Physical and Health Physical Education subjects in Ketapang Junior High School can be explained as follows:

(1) In the context aspect, 194\% stated "yes", the teacher carried out the assessment of learning outcomes, $6 \%$ stated "no", the teacher did not implement the learning outcome assessment objectives. This means that most of the curriculum field states that teachers carry out the assessment of learning outcomes in the Physical and Health Physical Education subjects

(2) .In the input aspect shows 95\% stated "yes", the teacher carried out the assessment plan of learning outcomes, 5\% stated "no", the teacher did not carry out the assessment plan of learning outcomes. This means that most of the curriculum field states that the teacher carries out the assessment of learning outcomes in Sports Physical and Health Education subjects.

(3) In the aspect of the process, 100\% states "yes", the teacher carries out the results assessment process. This means that all curriculum fields state that the teacher carries out the process of assessing learning outcomes in Sports Physical and Health Education subjects

(4) In the aspect of the product, $100 \%$ stated "yes", the teacher implemented the learning outcome assessment product. This means that all curriculum fields stated that the teacher carried out the product assessment of learning outcomes in Sports Physical and Health Education subjects.

From the overall results of the teacher questionnaire respondents, the results of student questionnaires, the results of observations of the teacher and the results of interviews with the field of Ketapang Junior High School curriculum based on aspects of context, input, process, and product can be concluded that the implementation of learning outcomes assessment system in Sport and Health Education general in accordance with the 2013 curriculum assessment guidelines.

\section{B. Discussion}


This research was conducted from June 4 to June 9, 2018, at Ketapang 1 State Junior High School, Ketapang 2 State Junior High School, Ketapang 3 State Junior High School, Ketapang 4 State Junior High School, and Hulu Sungai 1 State Junior High School. This research was conducted on PJOK subject teachers, field curriculum students, and seventh-grade students who attended PJOK lessons. Evaluation of learning outcomes assessment system in Health and Sports Physical Education Subjects in Ketapang Junior High School using CIPP model (context, input, process, product). The discussion in this study is explained as follows:

1) Context of assessment of learning outcomes in Health and Sports Physical Education subjects in Ketapang Junior High School.

Based on the results of the questionnaire of teachers, students, interviews, and obsolescence in the context aspect, the target of learning outcomes assessment in PJOK subjects in Ketapang Junior High School in general, the implementation of the learning outcomes assessment system has been implemented in accordance with the guidelines, but there are still deficiencies in the implementation of the attitudes and skills assessment objectives. . In the attitude assessment, there are shortcomings in the type of peer assessment and assessment through journals. The skills assessment deficiencies are found in the type of portfolio assessment and assessment through journals. The same thing also happened in Ani Widayanti's (2014) study that the preparation of portfolios which included planning, assigning tasks, compiling content, dialogue and storing portfolios was not good, the teachers carried out portfolio assessments in accordance with their simple understanding.

2) Input planning for assessment of learning outcomes in Health and Sports Physical Education subjects in Ketapang.

From the results of the questionnaire of teachers, students, interviews, and obsolescence in the aspects of planning input assessment of learning outcomes in PJOK subjects in Ketapang Junior High School, in general, the implementation of assessment planning learning outcomes have been implemented in accordance with the guidelines, but there are still deficiencies in its implementation, namely in the preparation of semester programs and forms RPP. In the preparation of the semester program, no special time is prepared in the daily test. In the preparation of the RPP, a small number of teachers were still not included in the problem text, key answers, and assessment guidelines. In the assessment instrument, there were still shortcomings of teachers not maximized in the preparation of assessment instruments through journals, projects, and portfolios.

This is in line with the results of Sadikun's research (2015) which shows that in general the implementation of the assessment system in schools has been carried out in accordance with the guidelines, but there are many deficiencies in its implementation. As for the drawback that the semester program does not contain the time to carry out repetition of repairs and enrichment, the syllabus does not include assessment techniques for aspects of attitude, cognitive and psychomotor aspects not relevant to basic competencies, assessment in RPP does not cover all learning objectives and still found assessment techniques that are not relevant to Learning objectives, assessment of affective aspects through journals is not carried out, the process of implementing portfolio assessments is not in accordance with the provisions of portfolio assessment.

3) The process of assessing learning outcomes in Health and Sports Physical Education subjects in Ketapang Junior High School.

From the results of questionnaires of teachers, students, interviews, and obsolescence in the aspects of the assessment process of learning outcomes in PJOK subjects in Ketapang Junior High School in general, the implementation of the assessment system of learning outcomes have been implemented in accordance with the guidelines, but there are still deficiencies in implementation. Still found the assessment process has not used observation sheets, portfolios, and journals. The assessment process is not yet in accordance with the time specified, the teacher has not optimally discussed UTS questions for material that has not been mastered. Similarly, the results of Ani Widayanti's (2014) study that the preparation of portfolios has not been good, teachers carry out portfolio assessments in accordance with their simple understanding. Sadikun (2015) shows that in general the implementation of the assessment system in schools has been carried out in accordance with the guidelines, but there are many deficiencies in the implementation. The drawback is that the semester program does not contain the time to carry out repetitions of repairs and enrichment.

4) Product assessment of learning the outcome of subjects at Ketapang Junior High School.

From the results of the questionnaire of teachers, students, interviews, and obsolescence in the aspect of product assessment report on learning outcomes in PJOK subjects in Ketapang Junior High School, in general, the implementation of the assessment system of learning outcomes have been carried out in accordance with the curriculum guidelines 2013. Reports on the assessment of student learning outcomes include affective aspects, cognitive and psychomotor as well as in the report have contained descriptive notes (teacher comments) so that it can be useful for the elderly and be a follow-up in the effort to improve the learning process. In accordance with Permen No. 104 of 2014 concerning the assessment of learning outcomes by educators in basic education and secondary education explains that assessment of learning outcomes is a process of gathering information about learning achievement that has been carried out by students in developing attitudes, knowledge, and skills competencies that are carried out systematically during and after the process learning. The provisions of the 
implementation of the 2013 curriculum, student report cards must be accompanied by descriptive notes (comments) of teachers. However, there are still deficiencies in the implementation, the teacher has not maximally provided enrichment to students. The same thing in Sadikun's research (2015) shows that in general the implementation of the assessment system in schools has been carried out in accordance with the guidelines, but there are many deficiencies in the implementation. As for the shortcomings that do not include the time of implementation of enrichment.

\section{CONCLUSION}

(1) Context of assessment of learning outcomes for Health and Sports Physical Education at Ketapang Junior High School.

The implementation of a system of assessing learning outcomes of Physical and Physical Education in Ketapang Junior High School in the aspect of the context of the assessment of learning outcomes, in its implementation, in general, is in accordance with the 2013 curriculum assessment guidelines. In the aspect of attitude assessment, a small number of teachers have not compiled instruments for observation sheets, peer assessments, and assessments through journals, in the aspect of skills assessment the teacher has not optimally compiled an assessment instrument for the project portfolio and assessment. This is due to a lack of training related to assessments by relevant agencies so that the teacher's understanding of the assessment objectives in the 2013 curriculum is not optimal.

(2) Input assessment of learning outcomes of Health and Sports Physical Education at Ketapang Junior High School.

Planning the assessment of learning outcomes in Health and Sports Physical Education subjects in Ketapang Junior High School in general in accordance with the 2013 curriculum assessment guidelines. However, there are still deficiencies in implementation. The preparation of the semester program and RPP a small portion has not included assessment instruments and daily review schedules. In the aspect of attitude assessment, teachers rarely conduct peer-to-peer assessments and assessments through journals, in the aspect of skills assessment the teacher always uses a practice test or assignment so that the assessment of the portfolio, the project is rarely carried out. This is due to a lack of training related to assessments by relevant agencies so that the teacher's understanding of the assessment objectives in the 2013 curriculum is not optimal. Planning assessment of learning outcomes is expected to be achieved in all aspects of the assessment so that the level of conformity with the assessment guidelines in the 2013 curriculum can be implemented $100 \%$.

(3) The process of evaluating the results of learning from Health and Sports Physical Education at Ketapang Junior High School.

The process of implementing a learning outcome assessment system in Health and Sports Physical Education subject at Ketapang Junior High School is generally in accordance with the 2013 curriculum assessment guidelines. Assessment through observation sheets, journals, and peer assessment has not been done for a small part so that the implementation process of the assessment has not been done optimally. In the 2013 curriculum assessment guidelines, all components of the assessment process must be carried out using all instruments.

(4) Product assessment of learning outcomes of Health and Sports Physical Education at Ketapang Junior High School

Forms of reports on the achievement of students' learning outcomes in the assessment of learning outcomes in Health and Sports Physical Education subjects at Ketapang Junior High School in general in accordance with the 2013 curriculum assessment guidelines. less and for those with more competence. Overall the form and content of the assessment report already contain a description (comment) from the teacher, so that the assessment report is useful for the teacher, parents and also as feedback for improvement in the learning process.

\section{REFERENCES}

Ismiyati. 2011. Evaluasi Sistem Penilaian Hasil Belajar pada Fakultas Ekonomi Universitas Negeri Semarang (Tesis). Yogyakarta: Universitas Negeri Yogyakarta.

Peraturan Menteri Pendidikan Dan Kebudayaan Republik Indonesia Nomor 104 Tahun 2014 tentang Penilaian Hasil Belajar Oleh Pendidik Pada Pendidikan Dasar Dan Pendidikan Menengah. Jakarta: Menteri Pendidikan Dan Kebudayaan Republik Indonesia.

Sadikun. 2015. Evaluasi Pelaksanaan Penilaian Autentik. Purwokerto

Satori, Djam'an dan Komariah, Aan. 2013. Metodologi Penelitian Kualitatif. Bandung: Alfabeta.

Widayati, Ani. Evaluasi Pelaksanaan Penilaian Portofolio dalam Pembelajaran. 